\title{
Et skabelsesteologisk perspektiv på Danne-Virke
}

\author{
af Helge Baden Nielsen
}

\section{Indledning}

Foredraget kommer til at falde i tre dele. Først vil jeg forsøge at belyse, hvad der ligger i - og hvorfor jeg finder det væsentligt - at anlægge et skabelsesteologisk synspunkt på tidsskriftet DanneVirke. Andet afsnit kommer til at handle om Grundtvigs opgør med den herskende filosofi - den transcendentalfilosofiske idealisme, som i en eller anden form også ligger til grund for romantikken. Og endelig i tredie afsnit kommer vi til at beskæftige os med Grundtvigs eget alternativ: hans forsøg på at hævde sandheden af den livsforståelse, der er indeholdt i den jødisk-kristne skabelsestanke. Det er jo det, der er den inderste nerve og hensigt i de Danne-Virke artikler, vi her skal beskæftige os med.

\section{Et skabelsesteologisk perspektiv}

\section{Andre mulige indfaldsvinkler til Danne-Virke}

Men allerførst: "Et skabelsesteologisk perspektiv på Danne-Virke « - hvad indebærer den titel? Selve formuleringen antyder jo, at andre perspektiver kunne være mulige.

Man kunne f.eks. tænke sig en litterær indfaldsvinkel, hvor man ud fra litteraturhistoriske, litterærkritiske og æstetiske kriterier søger at tolke og vurdere den blanding af digte og prosatekster af forskellig art, der udgør Danne-Virke, samtidig med at man søger at indplacere dem i samtidens litterære miljø. - Det har Flemming Lundgreen-Nielsen gjort i sin disputats fra 1980 »Det 
handlende ord ", hvor forfatterskabet fra 1798-1819 i sin helhed er taget under behandling, og hvor også læsningen af Danne-Virke har resulteret $i$ en række oplysende og spændende enkelt-analyser. Spørgsmålet, der rejser sig, er imidlertid, om man ad den vej i virkeligheden kommer afsted med at tolke Grundtvig ud fra det, der var hans egne forudsætninger. Lundgreen-Nielsen siger nok, at de "logiske ræsonnementer (med flittig brug af modsigelsens grundsætning), tilsyneladende humanistiske argumenter og den stoflige interesse for historien i "Danne-Virke«-årene peger under overfladen tilbage til kristendommen" (s. 707). Men det er efter mit skøn en for vag formulering. De litterære analyser når tilsyneladende ikke at få fat i det, der er sagen: at det er kristendommen og Grundtvigs lidenskabelige og eksistentielle interesse $i$ at hævde kristendommens sandhed, der dybest nede er den drivende kraft bag den kæmpe-indsats, det var, ene mand at udsende dette tidsskrift gennem fire år.

Danne-Virke kunne også tages i øjesyn i et udviklingshistorisk perspektiv, sådan som man vel kan sige, Kaj Thaning har gjort det $i$ sit forfatterskab, når han opfatter tidsskriftet som et led $i$ Grundtvigs opgør med sig selv. Ser det som et - ganske vist forgæves - forsøg fra Grundtvigs side på at skrive sig til klarhed; den klarhed han først nåede frem til i 1832, hvor Grundtvig ifølge Thaning blev "sig selv«. I Danne-Virke kører han imidlertid fast, hævder Thaning (Grundtvigs møde med Irenæus, Gr.St. 1953, s. 19). Men denne formulering synes jeg igen demonstrerer, at man ikke har fået fat på, hvad der egentlig er på færde, hvad der står på spil, og hvad der er Grundtvigs inderste intention med det, han bringer frem i sit tidsskrift.

I det hele taget er det jo karakteristisk, at man i tolkningen af Grundtvig i vid udstrækning har givet sig af med at inddele hans liv og arbejde i overskuelige perioder; sætte årstal på, hvornår de store brud og forandringer finder sted. Meget markant hos Kaj Thaning, når han slår fast: "Grundtvigs Liv og Arbejde har hidtil (i 1816) været delt i skarpt adskilte Perioder, hvoraf den tredie - i 1816 påbegyndte - skulde uddybe den første, skulde være Historikerens Forsøg paa at trænge til Bunds i den menneskelige Tilværelses Vilkaar. I den anden Periode har den lutherske Præst søgt at holde Folket til de gamle lutherske veje" (Gr.St. 1953, s. 19). 
På lignende måde hos Flemming Lundgreen-Nielsen, omend knap så udpræget, når han - ud fra sin litterære tilgang - inddeler forfatterskabet fra 1798-1819 i tre dele: en "overvejende klassicistisk-nyklassicistisk (1798-1804), en overvejende romantisk (1805-1810) « og endelig udtrykkelig i mangel af bedre ord en "grundtvigsk-nationalkristelig (1811-1819 med ny taktik fra julen 1815) «(s. 19).

Vist er det rigtigt, at der sker forandringer og brud. Undertiden også voldsomme opbrud $\mathrm{i}$ hans tankeverden. Som arbejdsredskaber - som hypoteser - som nogle markeringer, der kan hjælpe én til en slags overblik over et ellers helt uoverskueligt og rigt facetteret personligt udviklingsforløb hos Grundtvig, kan den slags være nyttige nok. Men det er væsentligt at slå fast, at de er og bliver fiktive. De dækker ikke - det gør den slags aldrig det virkelige liv, sådan som det er blevet levet og oplevet af den pågældende selv. Men det værste ved den slags inddelinger er, at de ofte - som erfaringen viser - kommer til at dække over eller skjule en grundlæggende sammenhæng, en indre konsistens - i dette tilfælde i Grundtvigs univers og tankeverden. Der bliver en tendens til at overse, at det blivende $\mathrm{i}$ alle omskiftelser er, at Grundtvig er teolog. Vist var han i en periode stærkt optaget af den romantiske digtnings muligheder og begrænsninger, vist optrådte han en tid som luthersk præst, for nu at anvende Thanings udtryk, og vist er han hele sit liv også historiker - men så spredt og så vidt omkring hans opmærksomhed også kom og rakte, den udsprang dog altid af hans teologiske engagement - af hans tro. Det er en del af forklaringen på foredragets titel: Et skabelsesteologisk perspektiv på Danne-Virke. I Biblens univers levede og åndede Grundtvig så at sige helt fra begyndelsen. Det var herudfra han tænkte og tog alting i verden i øjesyn.

\section{Grundtvigs bibelske univers}

At det forholder sig sådan mærkes allerede i Dagbogen, hvor Grundtvigs tro nok på mange måder kan karakteriseres som en art gammeltestamentlig forsynstro. Det er gammeltestamentlig billedbrug, der ligger bag, når han flere steder anvender udtrykket "hånd " om Guds både tugtende og nåderige førelse: "Hvi skød din Haand Mig ud paa det stormende Hav, og bød Mig tumles hen ad de brusende Bølger, uden engang at have Land $\mathrm{i}$ 
sigte, Jeg ved min Kæmpen og Stræben kunde haabe at naa?", skriver han i december 1805 (Dag-og Udtogsbøger, ved Gustav Albeck, s. 230). I digtet "De levendes land " er denne "hånd " i det afgørende vers 7 , hvor omslaget finder sted, smeltet sammen med Kærlighedens Aand «:

"O, Kiærligheds Aand!

Lad barnlig mig kysse din straalende Haand."

Også i hans første bog "Nordens Mytologi“, som kom frem i 1808, altså i det, man har kaldt hans romantiske periode, dukker det kristne tankeunivers op som hans egen egentlige baggrund og forudsætning. Han afslutter bogens anden afdeling om Asalæren med disse i denne sammenhæng overraskende - bemærkninger, som iøvrigt atter bringer det lige omtalte digt De levendes Land i erindring: "Ragnaroke maatte kommet, dersom ei en renere Søn af Alfader end Odin, var steget ned til den længselsfulde Jord, havde nedstyrtet Aserne fra deres uretmæssige Trone, frataget Jetterne den giftige Braad, oppustet den døende Guddomsgnist til en hellig, brændende Lue, og saaledes forsonet Jorden med Himmelen. Dette er den store Gudfrygtigheds Hemmelighed, som Vola ei kunde vide, som Døgnet ei vil vide. Ler kun I Kloge! Saa lo Eders Fader, for at Baldur ei skulde komme tilbage fra Hel. Ogsaa jeg kunde se Tingene fra Eders Standpunkt, thi jeg var der; men bevare mig Gud fra at komme der atter!!!" (V.i U. I. s. 222).

Går man nogle år længere frem, behøver man bare nævne den lige så berømte som berygtede Verdenskrønike af 1812 for at forvisse sig om, at bibelsk tankegang er hans udgangspunkt og hans egen tænknings horisont.

Noget af det, som nok i de sidste år har skærpet opmærksomheden for denne realitet og grundlæggende omstændighed, er udgivelsen af Grundvigs prædikener; i første omgang fra perioden 1822-37; men prædikenerne fra Præstø-tiden er jo på trapperne og Udbyprædikenerne følger måske efter? Grundtvig prædikede hele sit liv. Også mens han var på Langeland og i Valkendorf-tiden; ikke fast hver søndag, men alligevel jævnligt. Og så studerede han i sin Bibel, så han kunne den praktisk talt udenad. I sin almanak fra året 1813 har han således blandt meget andet holdt regnskab med sin læsning af Det nye Testamente. I december måned meddeler han: "Den 16de 
fuldendte jeg engang endnu det Ny Testamentes Giennemlæsning Gud være takket og lovet for sit hellige Ord, thi kun Hans Ord ere sande og trofaste" (Dag- og Udtogsbøger, s. 418). Det er ikke mindre end femte gang det år, Grundtvig făr læst Det nye Testamente igennem fra ende til anden. Så det kan ikke undre, at han formår at bevæge sig så frit omkring i dette univers. Det er heri han lever og ånder. Det er det, der gør ham så utrolig rig på indfald, som han er.

Sat på spidsen kunne man nok udtrykke det sådan, at i alle omskiftelser og brud er han i grunden den samme: en kristen tænker, der kæmper for at gøre sit budskab gældende som et vedkommende ord i tiden. Og det gælder hvadenten han arbejder som præst, som historiker og filosof, eller som digterspire under inspiration af den romantiske poetik. Han er frem for alt andet teo$\log$ - en kristen tænker.

Så kan man diskutere, hvilken tro han har eller på hvad måde troen er levende $\mathrm{i}$ ham $\mathrm{i}$ forskellige perioder af hans liv. I Langelandstiden kan man, som sagt, tale om en slags forsynstro - og karakterisere hans prædiken i hovedsagen som moralprædiken. Men skønt han her - i Dagbogen fra disse år - anvender udtryk som "Jesu hellige og skønne Lære", så er der allerede her en gryende erkendelse af, at kristendom ikke er lære men liv. "Hvorfra henter jeg Kraft til at udføre (Lovens) Bud, Kvægelse, naar jeg mattes i Kampen? «, spørger han i foråret 1806 (Dag- og Udtogsbøger, s. 366). Eller han spørger: "Hvad er da vel det, Jeg egentlig kan have at indvende mod de Nyes Definisjon af Poesien? " (Dagog Udtogsbøger, s. 222). Efter en længere indre dialog med sig selv kommer han frem til, hvad der er hans blivende indvending: at den poetiske eksistens, digterne foregøgler er en »blot tænkt eller ahnet Existents " - en umulighed, fordi de billeder for troen og eksistensen, digteren er i stand til at skabe ikke i sig selv rummer livgivende kraft. Der går en rød tråd gennem alle årene herfra til foråret og sommeren 1824, hvor det svar endelig som en befrielse sætter sig igennem hos ham og fæstner sig i ham - kommer til udtryk i prædikenerne og endelig i De levendes land: at liv i billederne og i ordene kommer der først, når kærligheds Ånd som en strålende hånd rækker over afgrunden fra himlen til jorderigs muld - rører øjet, rører støvet - levendegør det visnede løv. Kristendom er ikke lære - men liv! 
Det er på dette område - på teologiens felt - den egentlige udvikling i ham foregår. Ikke regelret og ikke efter en snor. Meget af det, han selv karakteriserer som nye opdagelser er ofte gen-opdagelser, allerede gjorte erkendelser, der melder sig og gør sig gældende i nye sammenhænge. Vi vandrer fra klarhed til klarhed, som han selv siger et sted. Udviklingen består $i$, at hans teologiske erkendelser uddybes og kommer til at omfatte og kaste lys over stadig større områder og partier af hans erfarings verden og virkelighed.

Fra en lidt anden synsvinkel kan det udtrykkes sådan: at det, der undertiden er blevet karakteriseret som noget indre: som omvendelser og sjælelige brud, det er ofte snarere noget ydre: forandringer $\mathrm{i}$ hans arbejdsmåde eller $\mathrm{i}$ hans måde at møde verden og sin samtid på.

Det gælder jo så oplagt i 1815 2. juledag, hvor ifølge Flemming Lundgreen-Nielsen "en inderlig rørt tilhængerskare " i Frederiksberg kirke hørte "Grundtvig prædike om 'Hvilen under Christi Vinger', efter samtidige udsagn en af hans bedste prædikener ", for så efter prædikenen til stor "forbavselse, bedrøvelse og forundring " at høre ham læse en erklæring op, hvori han nedlægger sit embede: "efter tre års forkyndelsesvirksomhed i københavnske kirker, hvor han uforsvaret af sine tilhørere offentligt var blevet bagvasket som fanatiker, partistifter og folkeforfører, vil han ikke prædike mere i hovedstaden, før den lovlige øvrighed forordner og befaler ham dertil. " Og han føjer til, at skridtet ikke er taget $\mathrm{i}$ angst for verden og at han forventer at den bundne tunge engang skal løses (Det handlende ord, s. 660 f.).

Det er ikke Grundtvig, der er blevet en anden her. Han er og bliver teologen Grundtvig. Han lægger derimod stilen om. Han ændrer taktik, som Lundgreen-Nielsen siger. Så vidt begrundelsen for udtrykkeligt at anlægge et teologisk perspektiv på DanneVirke og hævde det som det mest adækvate. Ikke som det eneste mulige, men som det mest fundamentale. 


\section{Opgøret med idealismen}

Om udtrykket "skabelsesteologi"

Herefter bevæger vi os ind i selve Danne-Virke, hvor vi først vil beskæftige os med hans opgør med den idealistiske filosofi. Men indledningsvis et par ord om, hvorfor det teologiske perspektiv i titlen ydermere præciseres som et "skabelsesteologisk " perspektiv.

Grundtvig havde nedlagt sit prædikantembede - taget kjolen af og iført sig frakken. Der var flere grunde til hans mismod. Bl.a. også skuffede forhåbninger og drømme om ansættelse i Norge ved det nyoprettede universitet eller $i$ kirken. Men frem for alt følte han sig misforstået. Hans akademiske kritikere (Rahbek, Baggesen o.a.) opfattede tonen $i$ hans kristne forkyndelse og engagement som hovmodig, intolerant og sværmerisk. Han fandt det uomgængeligt at lægge stilen om, gå andre veje, ændre taktik, som sagt. Han vil nu gøre troen, den kristne sag gældende på en ny måde - ikke oppe fra prædikestolen, men nedefra, kunne man sige: altså humant, filosofisk ved at knytte til ved dagligsproget, ved elementære livsfænomener og elementære menneskelige erfaringer. Han vil ikke be-vise, for det lader sig selvsagt ikke gøre, men vise, hævde, at den livstydning, der kommer til orde i den jødisk-kristne skabelsestanke er uimodsigeligt sand. Den kan et menneske ikke modsige uden samtidig at modsige sig selv og sine egne dybeste erfaringer.

Men inderst inde er hans ærinde det samme som for. Det er ham da også meget om at gøre at få slået fast, at selv om han har "skiftet tunge", så skal ingen mene, han har skiftet tro. Det bibelske billedsprog, det bibelske syn, troen - er stadig forudsætning og baggrund for det hele - også for hans filosofiske overvejelser. "At philosophere uden Tro er det samme som at ville see uden $\varnothing_{j n e}$ og at ville begribe sin Troe, er som at ville udrive sine $\varnothing_{j n e}$ for at giennemskue dem, men at sammenligne sin Troe med Slægtens og sin egen Erfaring, er at betragte Mennesket i et dunkelt Speil, i den Forudsætning, at vi der vel umuligt kan enten see Gud eller giennemskue os selv, men at vi upaatvivlelig maae se mangt et Spor af den Eviges Finger, mangt et Træk der røber hvad Troen forkyndte, og mangen en Gaade som vi kan føle er løst i Troen, skiøndt vi ej kan sige hvorledes" (DV II,s. 135). 
Han kalder sin gerning nu for en vækkergerning. Han vil, som før, vække en slægt, som han føler er nedsunket i "Blindhed, Dorskhed og Ligegyldighed ", vække mennesket, der "glemmer sig selv, glemmer sine dybeste Længsler og sine vigtigste Spørgsmål, Spørgsmål som giælde Alt, giælde Liv eller Død!« (DV II, s. $120 \mathrm{f}$.). Han udtrykker det også sådan: "medens derfor den Pen hviler og den Tunge tier, som jeg, saa synes det, har ført og rørt omsonst, da kalder jeg det Pligt at prøve, om Øiet er ligesaa blindt for Mennesket, dets Vilkaar og Trang, som for dets Frelser, om Øret er ligesaa døvt for den Sandheds Røst der lyder over Gravene og gienlyder i vort Inderste, som for den der nedtoner fra Oven og hensmelter Sandheds Tordenmæle i Kiærligheds livsalige Fugle-Kvad og Harpe-Klang" (s.st.).

Det er menneskelivet, som det er, Grundtvig vil have belyst. Men altså ikke rent filosofisk. Det er det skabte menneskeliv, mennesket skabt i Guds billede, der er hans udgangspunkt. Det er stadig en teo-logisk eller altså en skabelsesteologisk antropologi, han er ude på at gøre gældende, hævde og påstå som sand. Og deri ligner han jo Luther, som i sit opgør med Erasmus i De servo arbitrio netop siger: "Tolle assertiones, et Christianismum tulisti " (Clemen, bd. 3, s. 98), tag påstandene bort - og du har fjernet kristendommen.

\section{Opgørets teologiske begrundelse}

Grundtvig ligner også Luther på en anden måde. Ikke alene går det nemlig op for ham, at skal han komme på talefod med de dannede i sin samtid ud fra sine egne præmisser, sådan som han gerne vil, så må han påvise det uholdbare i den filosofiske tænkemåde, den intellektuelle elite er påvirket af. Man han bliver også klar over, hvor farligt det i det hele taget er for teologien at alliere sig med filosofien. Jeg er vis på, siger han, "at Christendommen, for at opfylde sin egenlige Bestemmelse: ved Troen at oprejse og saliggøre den faldne Slægt, ingenlunde trænger til Philosophien, eller kan have andet end Hug med den at skifte, og at Theologien, ved at tage Philosophien i Tjeneste, staar (i) samme Fare, som alle Fyrster, der omgiærde deres Throne med Leie-Tropper: lidt efter lidt at tabe Magten, og i det Høieste beholde Navnet, som Califen i Bagdad " (DV III, s. 226). Forlover man sig med én bestemt filosofisk tænkemåde, kan det ende med at man underminerer selve 
teologiens sag og selvstændighed. Det var baggrunden for Luthers opgør med den skolastiske tradition; og Grundtvig ser sig selv stående i en lignende kamp for at give teologien mulighed for overhovedet at komme til orde. "Hvem kiender Luther! Hvem læste ogsaa kun med Eftertanke hans Betragtning de servo arbitrio, og maa ei bekiende, at han havde været Mand for at reise en ganske anderledes Bygning end Melanchtons Loci; Mand for, i det Hele at ride Aristoteles til Vands" (DV III s. 223).

Hos dem begge galder det om - ikke at bygge et nyt system, det afvises atter og atter, men derimod at tænke historisk. De vil genindsætte sansningen, erfaringen, historien, dagligdagen som eneste kilde til "Videnskab og sund Menneskeforstand", det vil sige forstand på, hvad det er at være menneske. Og for Luther som for Grundtvig - for de tænker begge skabelsesteologisk, ud fra inkarnationen - for dem begge hører til vores erfaring og historie også det, Det gamle Testamente beretter om, at gennem profeter og digtere bliver Gud et ord i folkets liv. Som Skaber er Gud ikke den fjerne, men den nærværende; han taler til mennesket gennem det skabte og gennem historien - selvsagt også igennem den særlige historie, han gav sig selv i Jesus af Nazareths liv og skæbne.

\section{Grundtvig og idealismen}

Luther gjorde op med Aristoteles; Grundtvigs opgør rettede sig mod den transcendentalfilosofiske idealisme. Hans hovedanklage lyder på, at her er fornuften syndigt og afguderisk (DV III, s. 246) gået på egen hånd - er blevet en selvberoende og en selvspejlende fornuft, der foregiver uden om historien at kunne forklare menneskelivet. "Lod ikke Volf som om Historien ikke var til, paastod ikke Kant dens Ugyldighed, stræbte ikke Schelling at forvandle den til en blot Afbildning af Natur-Menneskets Udvikling og Forbillede paa dets Selvforklaring" (DV I, s. 125). Undertiden kan hans indsigelser virke noget summariske - og både samtid og eftertid har beklaget sig over hans unægtelige vidtløftighed (som man iøvrigt også beklagede sig over Luthers). Men han har svar på rede hånd: "... at bemærke det Udtryk om min Philosophie, at den er en kvælende Røg, (det finder jeg både) overordenlig smigrende, og temmelig træffende, thi hvad vil jeg dog i Grunden andet med min Philosophering, end ryge Ræve ud, som Theologien 
har stoppet for, eller, om de saa vil, ryge dem inde i Graven " (DV III, s. 202). - I virkeligheden er hans karakteristik af og indvendinger imod idealismen og romantikken yderst præcis. Med rette siger Henning Høirup i sin disputats: "Andre i Datiden kan have tilegnet sig Locke og Leibniz, Kant, Schelling og Fichte grundigere $\mathrm{i}$ enkeltheder, excerperende fra Paragraf til Paragraf, men ingen har som Grundtvig set, hvor deres hele Tænkning bar hen. Han slår ofte med en Havørns Sikkerhed ned på det centrale" (Grundtvigs Syn paa Tro og Erkendelse, s. 124).

Det gør han f.eks. i artiklen "Om det Philosophiske Aarhundrede «: "Om vi altsaa kan begribe det Høieste, det Første og det Sidste, beroer aabenbar paa om vi selv er det Høieste, det Første og det Sidste" (DV I, s. 113). Det er kernen i sagen. Hvad der står til debat er spørgsmålet: "... om Mennesket virkelig er sin egen Gud, om Mennesket er af sig selv (uafhængig) eller dog i sig selv (fri i strængeste Forstand) thi derpaa alene kommer det an " (DV I, s. 114).

Allerede i Dagbogen havde Grundtvig, som vi før var inde på, taget afstand fra denne tankegang. Han erfarede allerede her - på Langeland - selv det umulige i et "redde sig selv ", hæve sig "over den Lov, der byder Mennesket søge sine Problemers Løsning uden for sig selv " (Dag- og Udtogsbøger, s. 369). Nu føres opgøret med idealismen igennem både eksistentielt og erkendelsesteoretisk: Verden er ikke blot et menneskeligt udkast, afhængig af anskuelsesformer og forstandsformer. Verden er til som noget $i$ sig selv - som en skabt virkelighed uden for mennesket; en virkelighed, som gør indtryk - trykker sig ind i mennesket igennem sansningen - synssans og hørelsens sans især. Netop i sansningen er mennesket åben for verden, som den er i sig selv som skabt. Det er Grundtvigs modpåstand til idealismen.

Et illustrativt eksempel på, hvordan skabelsestankens eksistensforståelse og erkendelsesteori føres i felten imod den filosofi, der behersker samtidens elite, har vi i indledningen til artiklen "Om Mennesket i Verden" (DV II), hvor Kants udlægning af kategorierne tid og rum som "anskuelsesformer « i den menneskelige bevidsthed tages op til overvejelse. "Hvad er Verden? hvad er Tid? hvad er Rum? Man har sagt at Tid og Rum vare kun til i den menneskelige Forestilling, men noget mere bagvendt kunde man ikke lettelig sige, thi hvis saa var, da kunde Tiden og Rummet 
umuligt indskrcenke os, og Mennesket maatte være af sig selv, være sig selv bevidst som evig; er nu derimod Mennesket blevet til, da var Tiden førend han, thi kun i Tiden kan noget blive til, fremkomme, udvikles, skabes; Tidens og Verdens Virkelighed bliver Eet og det Samme, og lader sig ikke nægte med mindre vi vil nægte deres Virkning paa os, hvorved vi nægtede vor Bevidsthed " (DV II, s. 125).

Derefter udfolder Grundtvig så, hvad tid og rum er, set $i$ et skabelsesteologisk perspektiv. Tid og rum er ikke noget i sig selv, har ingen selvstændig virkelighed. De deler kår med alle andre timelige og skabte fænomener, at det Timelige er "kun Noget i og ved det Evige, som dets Aabenbarelse, har kun en laant Virkelighed, da det hverken er Aarsagen til sig selv eller indeholder den $\mathrm{i}$ sig, men er kun virkelig, som en Virkning, hvis Virksomhed ophører, saasnart Aarsagen ei længere vil være virksom paa denne Maade" (DV II, s. 125). Taget i og for sig selv er tid og rum virkelig intet, siger Grundtvig, i den meget præcise og prægnante betydning, at tiden i sig selv, det er løgnen, og rummet i sig selv, det er mørket. Som skabte, endelige fænomener kommer tid og rum på den måde til at stå som udtryk for strid. Tiden udtrykker kampen mellem sandhed og løgn; rummet udtrykker kampen mellem lys og mørke - "en Kamp, hvis første Optrin var Verdens Skabelse, og det andet er Menneske-Livet, det første var Mørkets, det andet skal blive Løgnens Undergang ", som Grundtvig formulerer det (DV II, s. 128). Det er ud fra denne duella mirabilis mellem lys og mørke, sandhed og løgn, Grundtvig har noget at sige om virkeligheden - altså om, hvad der virker og er på færde $\mathrm{i}$ verden og i et menneskes liv.

\section{Grundtvigs skabelsesteologi}

\section{System og fanomenologi}

Vi skal til slut samle opmærksomheden om Grundtvigs forsøg på at formulere et alternativ til den idealistiske filosofi. Men indledningsvis kan det nok være på sin plads atter engang at slå fast, at som Grundtvigs opgør med idealismen ikke gennemføres punkt for punkt, systematisk-filosofisk, sådan har det alternativ, han udkaster heller ikke systemets karakter. Det ligger der en pointe i. 
Det, der skal kastes lys over er jo det historiske menneskeliv, den gåde mennesket er som en eksisterende - den gåde, mennesket er også for sig selv. Det ligger i sagens natur, at opklaringen af denne gåde er det ikke muligt at komme til ende med. Det er derfor næppe nogen helt rigtig vurdering, når Thaning hævder, at Grundtvig i Danne-Virke kører fast eller kører træt. Sandheden er snarere den, at han drev sit oplysnings- og opklaringsarbejde så langt, som det var frugtbart for ham selv. De forskelligste steder sætter han ind; begreber og fænomener og fænomensammenhænge tages i øjesyn fra stadig skiftende indfaldsvinkler: sansning, indbildningskraft, fornuft, vilje og samvittighed, trosbegrebet, syndefald, historie, kunstens oprindelse og mere til. Hver artikel udgør et nyt tilløb til gådens forklaring. Det er sigende og karakteristisk, at titlen på alle de filosofiske afhandlinger i Danne-Virke indledes med et "om ": "Om Mennesket i Verden ", "Om Aabenbaringen, Konst og Vidskab« osv. I det følgende vil vi holde os til et enkelt centralt fænomen, Grundtvig beskæftiger sig med, nemlig sansningen.

\section{Grundtvigs opfattelse af filosofi og fornuft}

I god overensstemmelse med sine egne bibelske forudsætninger, nemlig inspireret af 1 . Kor. 13, sætter Grundtvig ind med en ny definition af, hvad filosofi er. "Philosophie er som man veed Udtryk for den menneskelige Stræben efter Viisdom, d.v.s. fuldkommen Erkiendelse, umiddelbar Anskuelse, og med det høieste christelige Udtryk: Beskuelse Ansigt til Ansigt. Det danske Ord vi da bedst kunne vælge til at betegne denne Stræben i sin Livlighed er uden tvivl Vidskab" (DV I, s. 110). Vidskabs hensigt og mål er "Tilværelsens Forklaring" (s.st. s. 112). I konsekvens af denne anden forståelse af filosofiens væsen, fremsætter han så herefter også en ny og anderledes opfattelse af den menneskelige fornuft. Fornuften er ikke et statisk, men et dynamisk begreb. "Fornuften i Menneske-Slægten ligesom i det enkelte Menneske er Begrebet og Udtrykket for den aandelige Vext og Udvikling", hedder det (DV I, s. 116). Fornuften er med andre ord udtryk for mennesket som en eksisterende, der stræber efter at komme til erkendelse af sig selv, udtryk for menneskets historicitet, hvorfor da også vidskab må præciseres som historisk videnskab. "Holde vi nu fast ved den klare Sandhed at det er det timelige Menneske vor 
Fornuft kan og skal begribe, da indsee vi let at al sand Vidskab maae i alle Maader være historisk, historisk fordi Fornuften finder intet i sig selv uden Maalestokken for timelig Sandhed, og maae udenfor sig søge Vidskabens Indhold, historisk, fordi Mennesket udvikler sig i Tiden og kan kun begribes i den, historisk, fordi den Maae være stykkevis og kan kun sluttes med Tiden" (DV II, s. 120). Historisk vidskab udtrykker altså menneskets stræben efter at begribe sig selv som en eksisterende.

\section{Sansningen}

Men allerede denne stræben bringer Grundtvig på sporet af det, han opfatter som et af de mest elementære træk ved den menneskelige tilværelse: sansningen - eller som han også udtrykker det: menneskets "Bekvemhed til at tage imod Indtryk «: "... naar Mennesket hverken er af eller i sig selv, naar det er en Skabning, ...da forudsætter al Virksomhed i ham og alt Værk af ham en Virkning paa hans Bestand-Dele, al aandig Virksomhed og alt aandigt Værk, en Virkning af Aanden paa Legemet og Bevidstheden; den sandselige Virksomhed forudsætter et sandseligt, den aandige en aandigt Indtryk, og hos Mennesket forudsættes kun en Bekvemhed til at tage imod Indtryk, der igien hverken kan være af eller i sig selv, men forudsætter en Beredelse af det der vil giøre Indtryk « (DV II s. 183 f.). Indtryk, indfald, sansning er hovedord i Grundtvigs teologiske antropologi - de mest fundamentale fænomener, han støder frem til som udtryk for menneskets skabthed: at mennesket har sin identitet udenfor sig selv; Luthers tale om "justitia aliena», den fremmede retfærdighed, fænomenologisk belyst.

Ikke underligt på den baggrund, at han karakteriserer det som en "gruelig Begivenhed, som er skeet i vore Dage (indenfor den herskende filosofi), da Fornuften, af Gru for Historien, gik reent fra Forstanden, erklærede, paa vanvittige Tyranners Viis, alle sine Haandlangere, Sandserne, for Forrædere, og murede sig inde i Spindelvæv, for dog at have noget for sig selv, og sidde paa sit eget" (DV III, s. 233).

Med hjemmel i bibelsk sprogbrug og menneskesyn anvender Grundtvig også udtrykket "hjerte" om den realitet, vi her er inde på. "Ved Hjertet forstaae vi nødvendig det Følende i os, eller os selv, forsaavidt vi føle, d.v.s.: modtage Indtryk, og da vi nu ikke 
ere af os selv, saa er nødvendig Følelse Livets Begyndelse, og vor sande Personlighed det Indtryk, Forestillingen om vor afmaalte Tilværelse giør paa vort Legeme" (DV III, s. 254). - Det er "Følelsens Sands vi skylder Begrebet om os selv «, siger han også (DV II, s. 154). I afhandlingen "Om Mennesket i Verden" tager han udgangspunkt i "Haand-Følelsen" som den elementæreste af alle sanser. Med hånden føler jeg, jeg har et legeme. Der er etableret et forhold mellem et jeg og et legeme. Jeg er blevet bevidst om mig selv. I og med "Haand-Følelsen" er allerede "Selv-Bevidstheden " en realitet. "Dette er vigtigere, end det maaskee synes, thi hint tydelige Begreb er netop den fornuftige Selv-Bevidsthed, uden hvilken al Selv-Betragtning, og alle tydelige Begreber om Tingene $\mathrm{i}$ deres Forhold til hinanden indbyrdes og til os, vare umulige" (DV II, s. 154).

Denne sanselige eller legemlige selv-bevidsthed peger imidlertid ud over sig selv, fører - logisk, eller unægteligt som Grundtvig siger - over i den fornuftige eller "åndelige selvbevidsthed ". For allerede ved grunderfaringen af sit eget legeme, har mennesket jo grebet sig selv "i Tiden og Rummet, som timelig og afhængig, og begrebet, at han ikke kunne kalde sig uafhængig, uden at modsige sig selv, ...han begreb, at han var ikke af sig selv men af hvad han ikke vidste, og som dog maatte vides af Een, da en afhængig Selv-Bevidsthed forudsætter en høiere Selv-Bevidsthed hvori den, med Alt hvad den omfatter, har sin Grund, en Selv-Bevidsthed altsaa, der indeholder Grunden til alt Timeligt og er følgelig evig, thi kun i Tiden kan Noget begyndes " (DV II, s. 158).

Som en art konklusion på dette eksistens-logiske forløb, som man kan kalde det, siger Grundtvig: "At begribe sig selv i Sandheden det er da det store Maal for den menneskelige Fornuft, Høiden af menneskelig Vidskab, og det første Skridt dertil er Fornuftens aandelige Selv-Bevidsthed i Sandheden, Vedkiendelsen af sig selv i sit sande Forhold til det Evige, til den guddommelige Fornuft og Sandhed. (DV I, s. 117)

Filosofi på skabelsestroens forudsatning Hele denne tankegang hviler nu imidlertid, som det flere gange er blevet fremhævet, på en ganske bestemt teologisk forudsætning, nemlig skabelsens virkelighed, eller inkarnationens virkelighed: 
at mennesket er skabt i Guds billede, at Gud ved sit ord har skabt verden og afbildet sig selv i mennesket.

"Det er jo og indlysende, at skal Mennesket nogensinde komme til at fatte og begribe sig i Sandhed, som den evige Sandheds jordiske Billede, da maae han virkelig vare det, have været det ligefra Begyndelsen, da maae den evige Sandhed have aabenbaret sig i ham og for ham ligefra og i hans Begyndelse, da maae den evige Sandhed selv have indaandet ham Livet, og ladet ham i Aanden høre sin Røst « (DV I, s. 121 f.). - Men denne teologiske forudsætning bevises ikke, men bekraftes på sin side af selve den menneskelige tilværelses struktur og forfatning. Atter er det sansningen, der har Grundtvigs interesse og opmærksomhed, synssansen og hørelsens sans. Sansningen, forstået passivt, som modtagelse af indtryk, ser han som den afgørende forudsætning både for at Gud kan åbenbare sig for mennesket og for at Gud kan afbilde sig selv i mennesket. Han siger: "At see (herunder også i et åndeligt syn at se sig selv i Skaberen som betingelse for at udtrykke Skaberen i sig) er ikke nogen Gierning af Seeren, men en Sandsning, ikke Speilet men Gienstanden, eller rettere den som skabte dem og deres Forhold, giør Synet, og et aandigt Syn, (som) viser sig selv i et sandseligt Speil, er en Aabenbaring "(DV III, s. 262). Det, der formidler dette åndelige syn til det timelige, sanselige menneske, er ordet. Ordet er det element, hvori evigt og timeligt forenes, fordi ordet er på een gang både lyd og legeme - altså et sanseligt, hørligt ord; men ordet er også ånd: billed-bærer og betydningsbærer.

Vi kan altså slutte med at konstatere en cirkelstruktur i Grundtvigs skabelsesteologiske tankegang. Hans udgangspunkt er skabelsens virkelighed, skabelsestroen, som bekræftes af erfaringen og selve den menneskelige tilværelses indretning. Men omvendt galder tilsvarende: det er ham umuligt at tage udgangspunkt i det timelige, sanselige menneskeliv, uden at modsætningen mellem sandhed og løgn, lys og mørke øjeblikkelig har bragt spørgsmålet om ånd og evighed på bane. 


\section{Slutning}

Og her står vi da ved det, der er Grundtvigs hovedintention i Danne-Virke: at hævde skabelsestankens livsforståelse som noget uimodsigeligt. Han ville kaste lys over den uløselige forbindelse, han mener der er mellem kristendom og menneskeliv, så han kunne stå rustet på en ny måde, når han endelig igen blev kaldet til det han helst ville: gøre kristendommen gældende som prædikant. Det blev han i foråret 1821, da han uventet blev udnævnt til sognepræst i Præstø. Det skulle vise sig, at de erkendelser, han gjorde i Danne-Virke kom til at bære frugt i hans prædikener - og de fik ham siden til at opdage sit åndsfællesskab med kirkefaderen Irenæus. Det han mødte i hans bøger, kom til at bekræfte ham i hans eget skabelsesteologiske syn, som det havde klaret sig for ham i årene fra 1816-1819. 